\title{
Pathological and clinical study of calcification of the mitral valve ring
}

\author{
ARIELA POMERANCE ${ }^{1}$ \\ From the Department of Histopathology, Central Middlesex Hospital, London
}

SYNOPSIS The pathology and clinical features of 258 cases of mitral ring calcification were reviewed. The overall incidence in patients over 50 years of age was $8.5 \%$; it was mor than twice as high in women $(11.5 \%)$ as in men $(4.5 \%)$ and rose sharply with age.

Cardiac failure and systolic murmurs were each noted in over half the patients. Hypertension was slightly commoner than in age- and sex-matched groups without ring calcification, although the difference was not statistically significant.

Small nodules of calcification were more frequent in men and heavy deposits in women Distortion and atrial displacement of the posterior mitral cusp was present in $26 \%$ of the hearts with early ring calcification, in $56 \%$ of the hearts with moderate, and in almost a hearts with marked changes. Systolic murmurs had been heard in $73 \%$ of these cases. 'Caseation? of the calcified ring was seen in seven hearts and haemorrhagic valvulitis in three. Calciun had ulcerated through the cusp in 12 cases, with thrombotic and/or bacterial endocarditis in five. Aortic valve calcification was present in $36 \%$ of men and was quantitatively relate to the severity of mitral ring calcification. In women the incidence was $30 \%$ and there was nes corresponding quantitative relationship.

Microscopy showed nonspecific chronic inflammatory changes adjacent to calcium in about half the cases in both sexes, with foreign body type giant cells in $6 \%$. Similar inflamg matory changes in the valve cusp were almost twice as common in women as in men.

There was no evidence that previous endocarditis was responsible for mitral ring calcife cation, neither did parity influence its incidence. Severe coronary atherosclerosis was unrelated but severe aortic atherosclerosis was commoner in patients with calcified mitral rings. The difference, in women, was statistically significant.

The higher incidence of severe degrees of ring calcification, complications, and valvulart inflammation in women suggests a sex-determined difference in tissue response in the mitra area. Possible provoking factors apply to both sexes and both left side valves, and such difference would account for the relative frequency and sex incidence of mitral ring calciffs cation.

Calcification of the mitral valve ring is one of the commonest cardiac abnormalities encountered in necropsies at general hospitals, yet it is not mentioned in standard British reference books of cardiology (Wood, 1968) or systematic pathology (Wright and Symmers, 1966) and even

${ }^{1}$ In receipt of a grant from the British Heart Foundation

Received for publication 21 August 1969.
Hudson's 'Cardiac pathology' (1965) gives on one line of text to this condition. It is therefors not surprising that in Britain mitral ring calcif cation is largely ignored or dismissed as of no clinical or pathological importance, althoug in the USA it is now becoming recognized as clinically significant disease (New England Journet of Medicine, 1962; Friedberg, 1966; Hurst and Logue, 1966). 


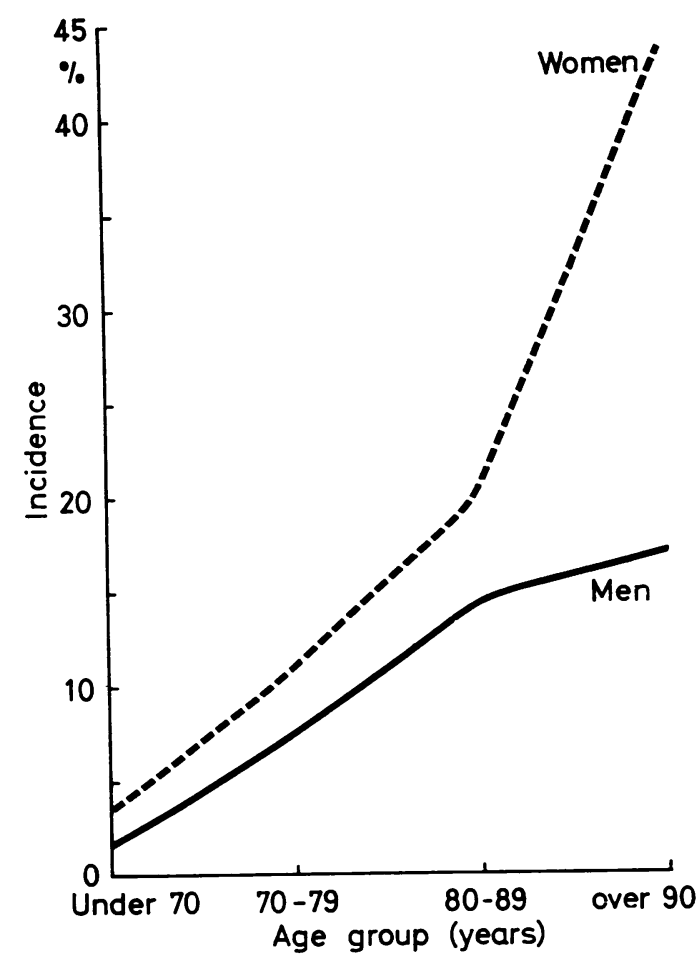

Fig. 1 The relation of age and sex to the incidence of mitral ring calcification.

\begin{tabular}{|c|c|c|c|}
\hline & & $\begin{array}{l}\text { Cases with Mitral } \\
\text { Ring Calcification }\end{array}$ & $\begin{array}{l}\text { Cases without Mitral } \\
\text { Ring Calcification }\end{array}$ \\
\hline Hypertensive & $\begin{array}{l}\text { Men } \\
\text { Women }\end{array}$ & $\begin{array}{l}10 / 72(14 \%) \\
34 / 165(20 \%)\end{array}$ & $\begin{array}{l}11 / 96(12 \%) \\
20 / 156(13 \%)\left(x^{2}=3.47\right)\end{array}$ \\
\hline $\begin{array}{l}\text { Severe aortic } \\
\text { atherosclerosis }\end{array}$ & $\begin{array}{l}\text { Men } \\
\text { Women }\end{array}$ & $\begin{array}{l}30 / 76(40 \%) \\
53 / 170(31 \%)\end{array}$ & $\begin{array}{l}24 / 96(25 \%)\left(x^{2}=4 \cdot 12\right) \\
30 / 162(19 \%)\left(x^{2}=7 \cdot 085\right)\end{array}$ \\
\hline $\begin{array}{l}\text { Severe coronary } \\
\text { atherosclerosis }\end{array}$ & $\begin{array}{l}\text { Men } \\
\text { Women }\end{array}$ & $\begin{array}{l}21 / 81(25 \%) \\
42 / 166(25 \%)\end{array}$ & $\begin{array}{l}23 / 96(24 \%) \\
29 / 159(18 \%)\left(x^{2}=4 \cdot 86\right)\end{array}$ \\
\hline $\begin{array}{r}\text { Parity } \underset{1-3}{0} \\
\text { over } 3\end{array}$ & & $\begin{array}{ll}29 & (25 \%) \\
67 & (54 \%) \\
28 & (23 \%)\end{array}$ & $\begin{array}{ll}15 & (13 \%) \\
83 & (75 \%) \\
13 & (12 \%)\end{array}$ \\
\hline
\end{tabular}

Table I Possible pathogenic factors

\begin{tabular}{|c|c|c|c|}
\hline \multirow[b]{2}{*}{ Pathology } & \multicolumn{2}{|l|}{ Incidence } & \multirow[b]{2}{*}{ Total } \\
\hline & Men & Women & \\
\hline $\begin{array}{l}\text { Early calcification } \\
\text { Moderate calcification } \\
\text { Marked calcification } \\
\text { Caseation } \\
\text { Ulceration through }\end{array}$ & $\begin{array}{l}85(4.6 \%) \\
48(56.5 \%) \\
22(26 \%) \\
15(17.5 \%) \\
1\end{array}$ & $\begin{array}{l}173(11 \cdot 5 \%) \\
55(32 \%) \\
44(25 \%) \\
74(43 \%) \\
6\end{array}$ & $\begin{array}{l}258(8.5 \%) \\
103(40 \%) \\
66(26 \%) \\
89(34 \%) \\
7\end{array}$ \\
\hline $\begin{array}{l}\text { cusp } \\
\text { Thrombotic }\end{array}$ & 1 & 11 & 12 \\
\hline $\begin{array}{l}\text { endocarditis } \\
\text { Bacterial endocarditis } \\
\text { Haemorrhagic }\end{array}$ & $\begin{array}{l}\mathbf{0} \\
\mathbf{0}\end{array}$ & $\begin{array}{l}4^{1} \\
3^{1}\end{array}$ & $\begin{array}{l}4 \\
3\end{array}$ \\
\hline valvulitis & 0 & 3 & 3 \\
\hline
\end{tabular}

Table II Pathological findings in mitral ring calcification

${ }^{1}$ Bacterial infection of the distal part of a large thrombus.
Incidence, Age, and Sex

Macroscopic (ie, visible and palpable) calcifi $\frac{\frac{\rho}{\bar{J}}}{0}$ cation of the mitral valve ring was seen ine $258(8.5 \%)$ of 3,334 necropsies on patients over 50 years of age. It was over twice as common in females $(11.5 \%)$ as in males $(4.6 \%$ and was strikingly related to aging. The incidence rose with age from $1.4 \%$ in men under 70 yearso to $17 \%$ in those over 90 , and women showed an even sharper increase, from $3.2 \%$ to $43.5 \%$ (Fig. 1).

\section{Clinical Features}

Hypertension had been present in $19 \%$ of all cases $(14 \%$ of the men and $20 \%$ of the women) This incidence was higher than in an age- andw sex-matched group without mitral ring calcifi $\nRightarrow$ cation, where $11.5 \%$ of men and $13 \%$ of womeng had been hypertensive (Table I), but the difference was not statistically significant even fos the women.

The relation between cardiac failure and mitrato ring calcification has been fully discussed in as previous study (Pomerance, 1965); 53\% of pa: tients were in failure but most also had othero cardiac pathology and ring calcification was the sole abnormality in only 3 per cent.

Systolic murmurs had been noted in $55 \%$ of the cases, varying from soft localized apica? to harsh precordial conducted to the axilla $\overrightarrow{\overrightarrow{0}}$ This finding was more frequent in patients in whom distortion of the posterior mitral cusp was subsequently found. Murmurs had been. heard in $73 \%$ of this group compared with only $23 \%$ of those with early or moderate degrees of mitral ring calcification without distortion.

Electrocardiographs were available in onls 25 cases but 10 showed conduction abnormalities one man had complete atrioventricular blocko and four men and five women, a bundle branch? block.

\section{Gross Pathology}

The degree of calcification varied from a smalt localized nodule or spicule to massive involve ment of the whole ring; 103 hearts $(56.5 \%$ op the 85 men and $32 \%$ of the 173 women) had earlyo calcification only with small foci of calcification under the posterior mitral cusp, usually at its junction with anterior cusp and septum or ir the central part of the ring (Table II). In mosf of these cases the normal anatomical relation ships of the cusp were not disturbed but in $26 \%$ part of the calcified mass formed a spur projecting into the left atrium with distortion of the overe lying part of the cusp. 


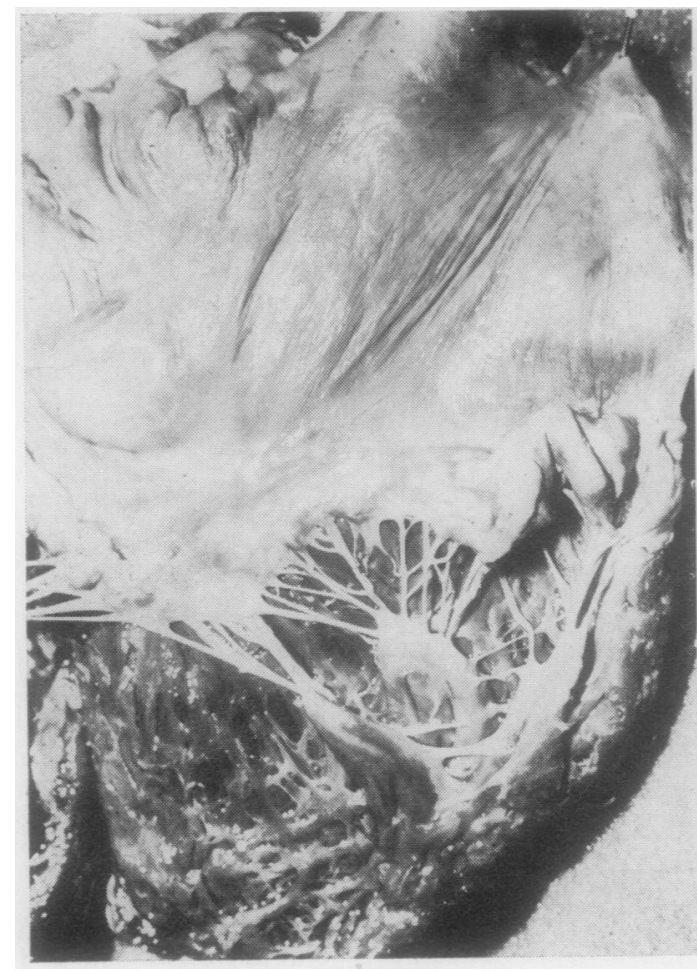

Fig. 2 Opened left side of heart showing distortion and fixed atrial displacement of part of the posterior mitral cusp by a spur of calcification from a moderately calcified ring. (The patient had a mitral pansystolic murmur.)

Sixty-six hearts showed moderate degrees of mitral ring calcification, with more extensive deposits than in early cases but not extending along the whole valve ring. Atrial displacement and distortion of the posterior cusp was present in $56 \%$ of cases (Fig. 2).

The remaining 89 hearts $(17.5 \%$ of the men and $43 \%$ of the women) had severe changes, with a rigid curved bar of calcium up to $2 \mathrm{~cm}$ diameter occupying the whole mitral ring zone. These cases almost invariably showed distortion and atrial displacement of the posterior cusp. In the few exceptions, spread of calcification had been predominantly in a downward direction and in two hearts the calcified bar had become surrounded by thick fibrous tissue, forming an apparently fleshy subvalvular shelf.

In seven cases the calcified rings were not uniformly solid, but showed extensive central caseation; in the only example in a man the pultaceous material extended into the posterior cusp forming an 'abscess' (Fig. 3). Microscopy showed no granulomas or other evidence of tuberculosis or fungal infection. Ulceration and extrusion of calcium through the overlapping cusp (Fig. 4) was also not uncommon, being present in one man and 11 women with severe ring calcification. Thrombotic endocarditis had

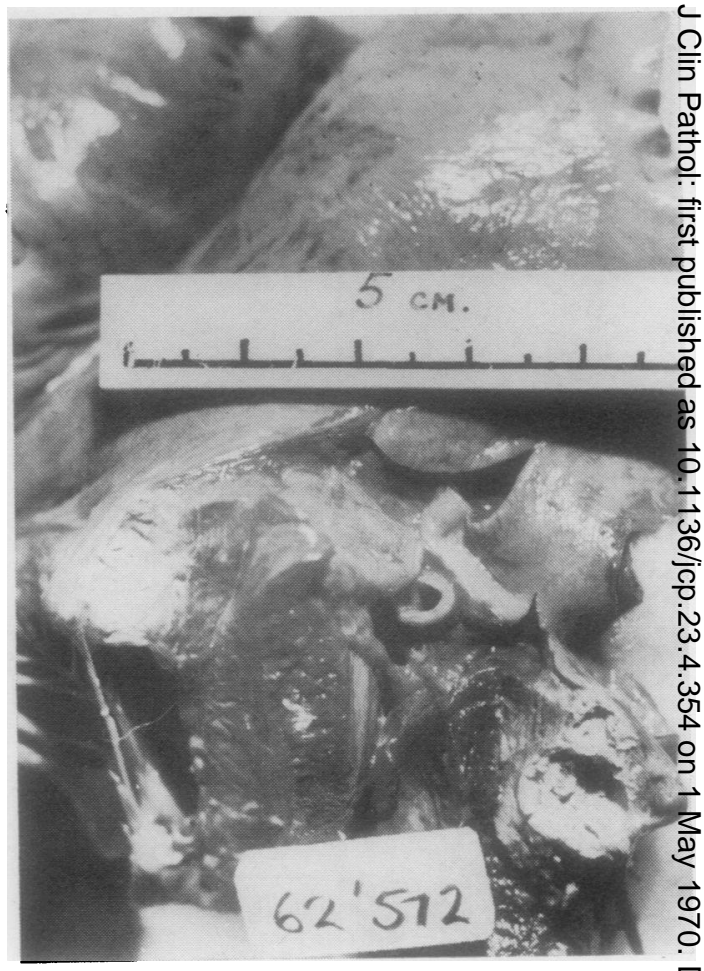

Fig. 3 Posterior wall of left ventricle, bisected through the mitral cusp to show a caseous mass extending from the ring into the posterior cusp, which was expanded and immobilized by pultaceous material.

occurred in four of these cases, in two of whict the thrombus was pedunculated and large enough partly to obstruct the mitral orifice (Fig. 5) Bacterial endocarditis was present in threewomen, one of whom died from embolic staphy lococcal meningitis (Fig. 6). An acute haemoro rhagic valvulitis (Fig. 7) without endocardiaß breakdown was seen in three women, and mitras stenosis of chronic rheumatic type in a furthes three. Eight patients of each sex showed minor non-specific postinflammatory scarring of the anterior mitral cusps.

Small deposits of calcium were present if the aortic cusps of $18 \%$ of the men and heavied ones in a further $18 \%$. The proportion of women with aortic cusp calcification was lower-15\% in each group. In men, severity of aortic calciff cation was related to that of mitral ring calciff? cation (Table III) but no such relationship wass present in the women.

\section{MICROSCOPIC PATHOLOGY}

Sections stained with haematoxylin and eosiu and Weigert's elastic and Van Geison stains were examined from the first 100 examples studied. The blocks were taken to include a palpably calcifie segment of ring with adjacent atrium and ventricle 


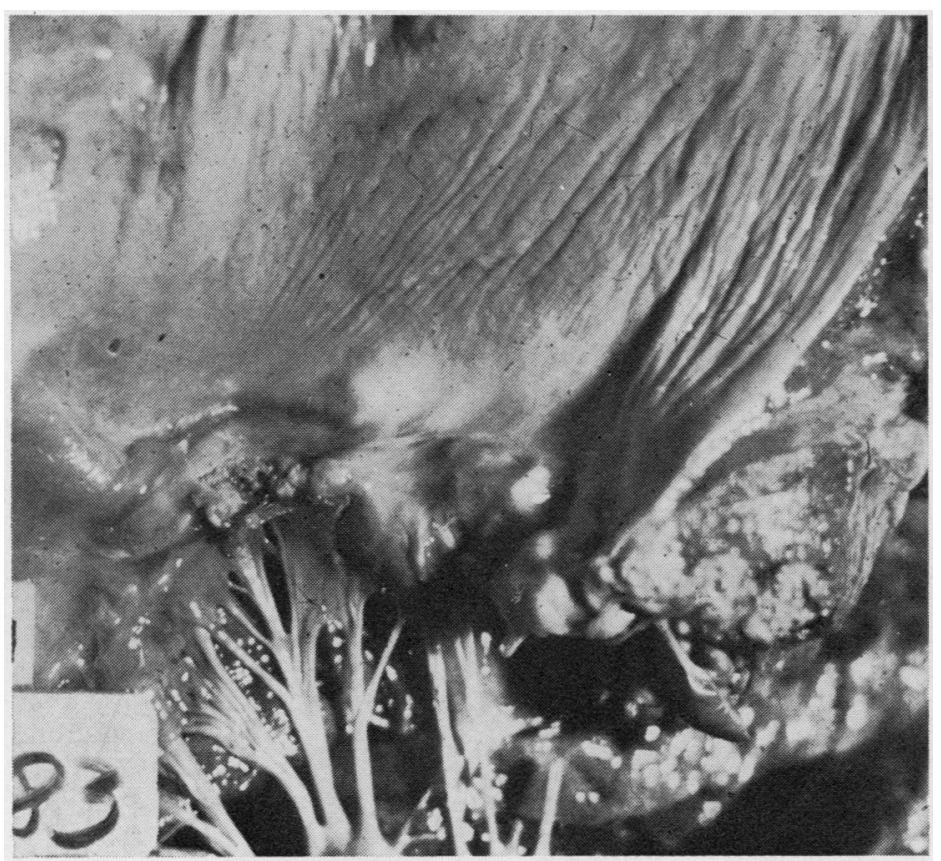

Fig. 4 Opened left atrium and mitral valve with severe ring calcification and a mass of calcium ulcerating through the medial commissure.

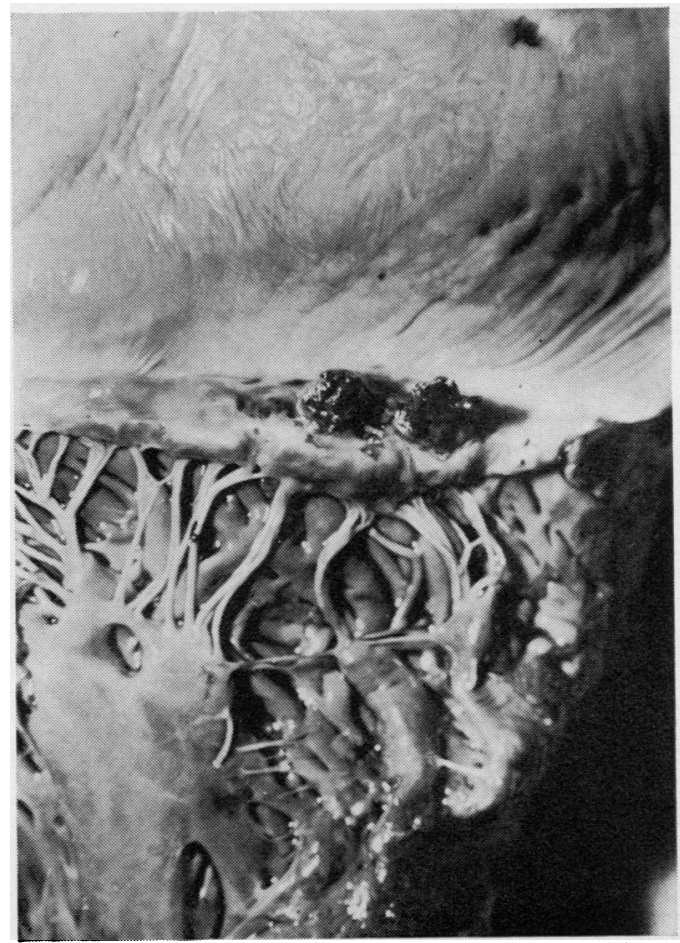

Fig. 6 Opened left side of heart showing a large mass of vegetations (staphylococcal) on a posterior mitral cusp distorted by ring calcification.

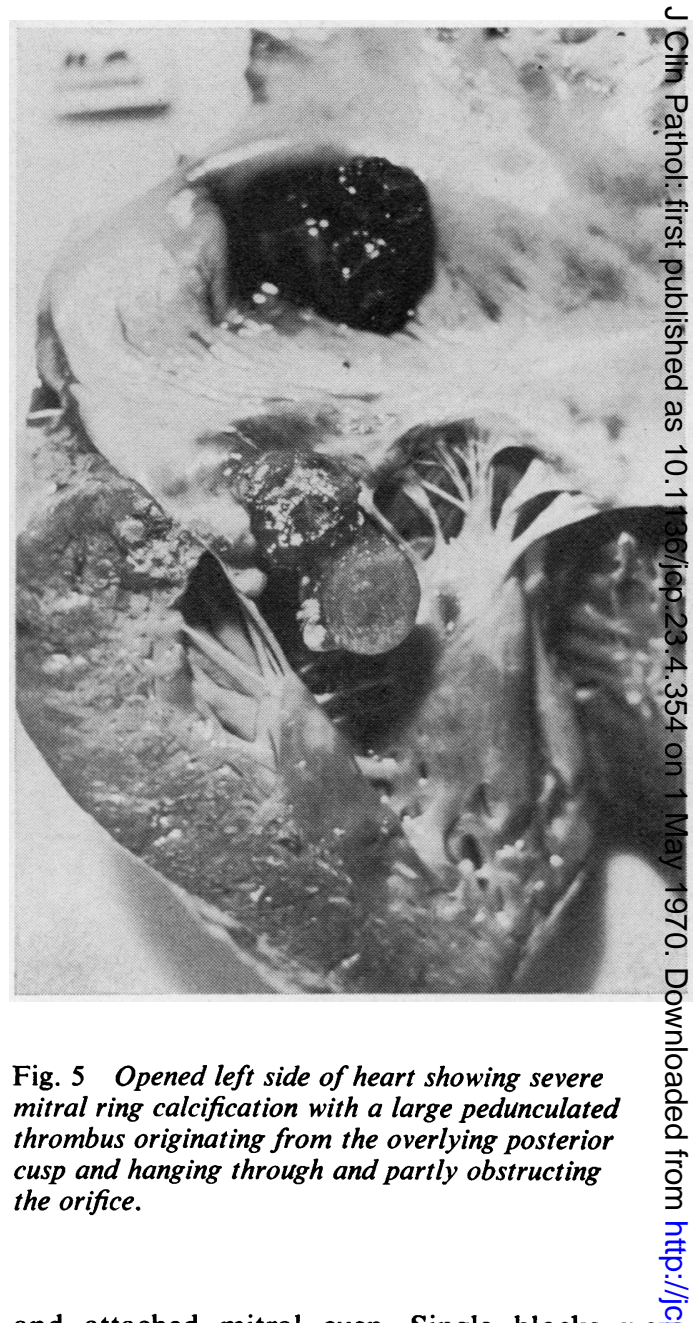

and attached mitral cusp. Single blocks we⿳⺈: selected from cases with early or moderate calcif cation and two or more from those with severe of complicated calcification of the mitral ring.

The calcification appeared as large amorphous basophilic areas surrounded by a variable amount of fibrous tissue. Cartilage was present in two cases (Fig. 8) but no true bone formation. was seen.

Inflammatory changes (Fig. 9) were frequent around the calcified masses. They varied from $\$$ few dilated vascular channels with scantgo lymphocytes and plasma cells to dense cellula infiltration, including numerous polymorpks and extending between the myocardial fibres of the posterior wall for several millimetres. Inflammatory changes were present in $53 \%$ of the 100 hearts sectioned, $55 \%$ of men and $52 \%$ of women. In 33 of the 53 cases these changes were not limited to the zone surrounding the valve ring, but also involved the overlying cusp. This finding was more common in the women $(70 \%$ of the 41 cases with inflammatow changes) than in the men $(33 \%)$.

Haemosiderin-containing macrophages were 


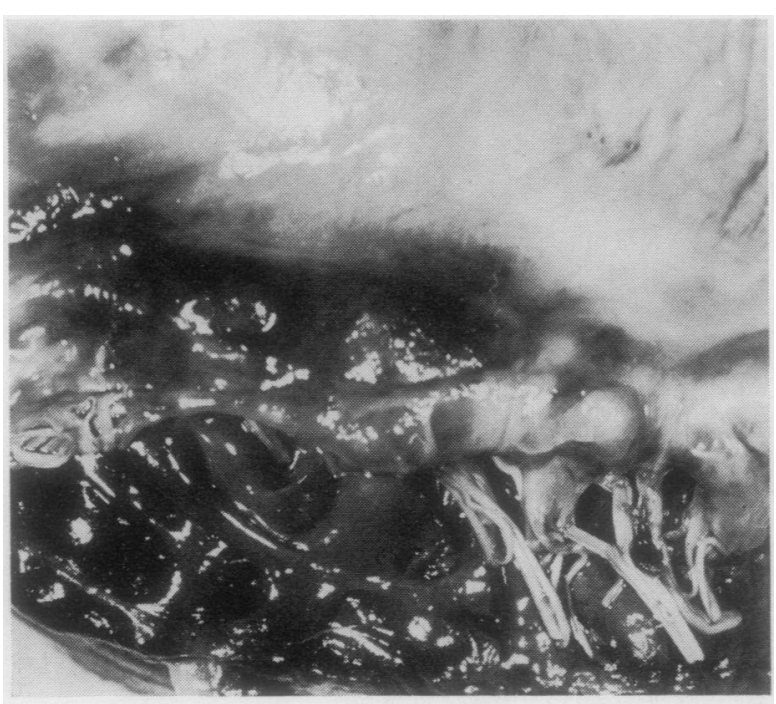

Fig. 7 Part of opened left side of the heart showing a large haemorrhagic area involving most of the posterior cusp. Severe ring calcification present.

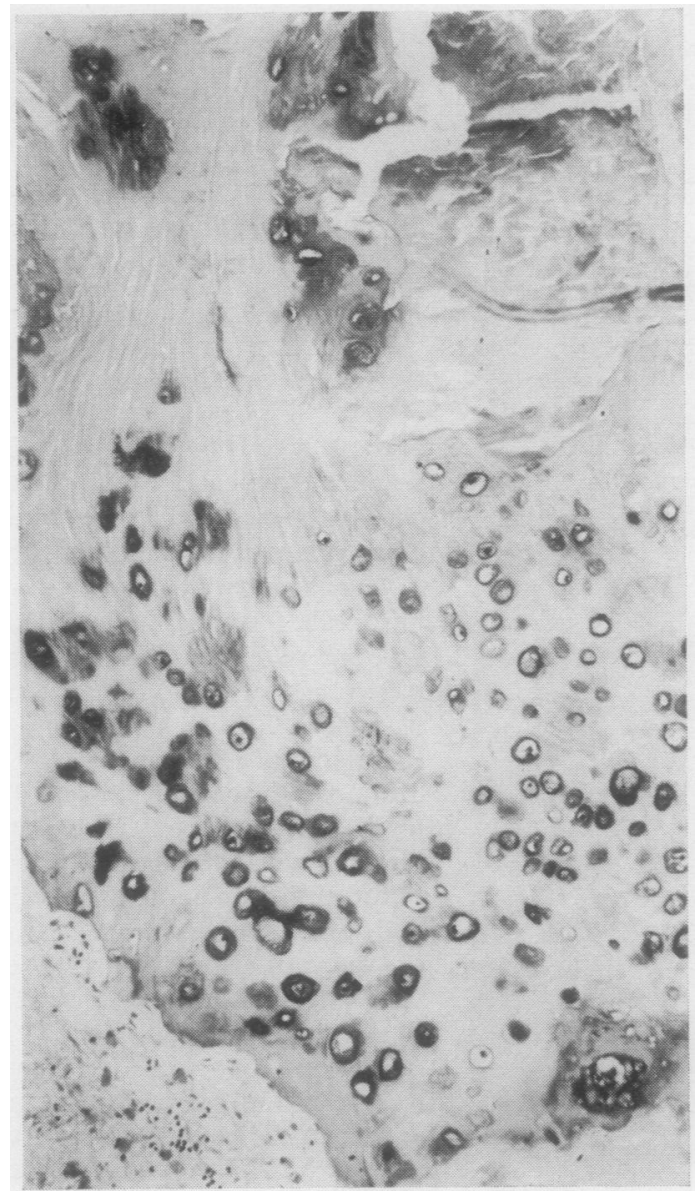

Fig. 8 Section through a calcified mitral ring showing an area of cartilage formation (haematoxylin and eosin, $\times 127)$.

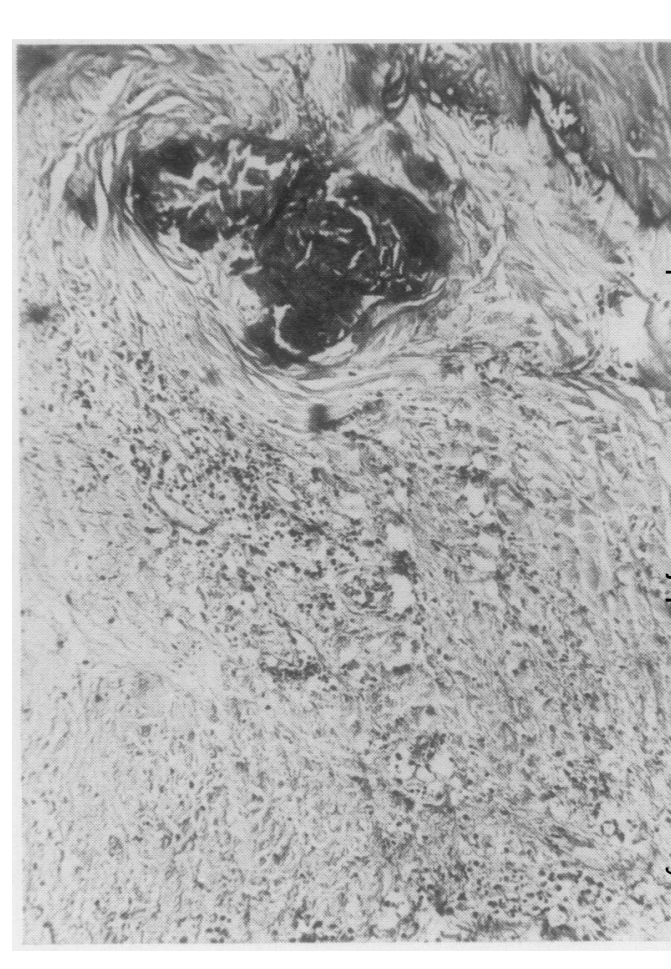

Fig. 9 Section through calcified mitral ring and adjacent tissue showing fibrosis, capillary channels, and moderate lymphocytic infiltration around the calcification (haematoxylin and eosin, $\times 90$ ).

frequently seen but recent haemorrhage was surprisingly rare. Other occasional finding included groups of foreign body type gian cells in six cases (Fig. 10), zones of pallisadeg fibroblasts (Fig. 11) in two cases (neither with rheumatoid disease), and a large number of tissuio mast cells in one case.

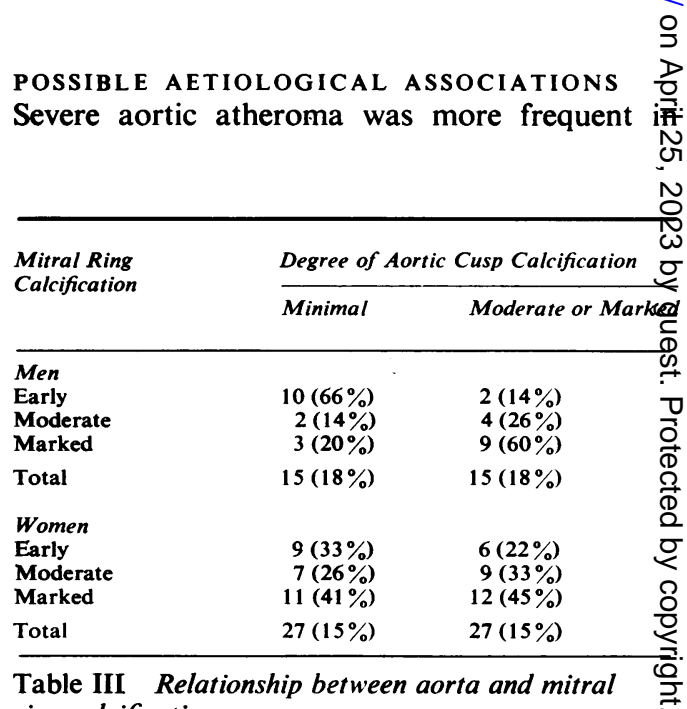
ring calcification 


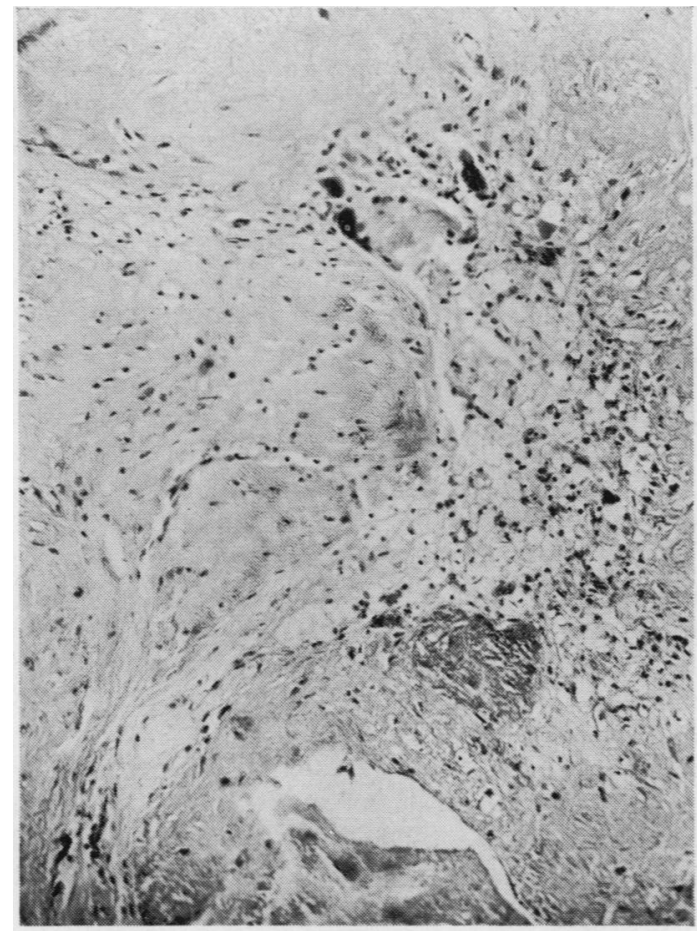

Fig. 10 Photomicrograph of inflammatory changes adjacent to mitral ring calcification, showing a group of multinucleate giant cells (haematoxylin and eosin, $\times 135$ ).

cases with mitral ring calcification than in the age- and sex-matched groups without this abnormality. Of the men with ring calcification, $40 \%$ had marked aortic changes compared with $25 \%$ of those without. In women the corresponding figures were $31 \%$ and $19 \%$, and this difference was statistically highly significant. There was no similar correlation with severe coronary atherosclerosis which had virtually the same incidence in men with and without mitral ring calcification and was only slightly more frequent in the women with ring calcification (Table I).

The higher incidence of mitral ring calcification in women suggests that hormonal factors may be concerned in pathogenesis; however, the only man known to have been on prolonged stilboesterol therapy did not have ring calcification, neither did the two women with unusually early termination of ovarian function (at 29 and 39 years): The increased cardiovascular stresses of pregnancy are clearly another possible factor, but although $23 \%$ of women with ring calcification had more than three children, compared with only $12 \%$ of those without calcification, the proportion of nulliparous women in each group was almost the same, $23 \%$ and $13 \%$ respectively. No information could be obtained about lactation history, which would have been of interest in view of the influence of

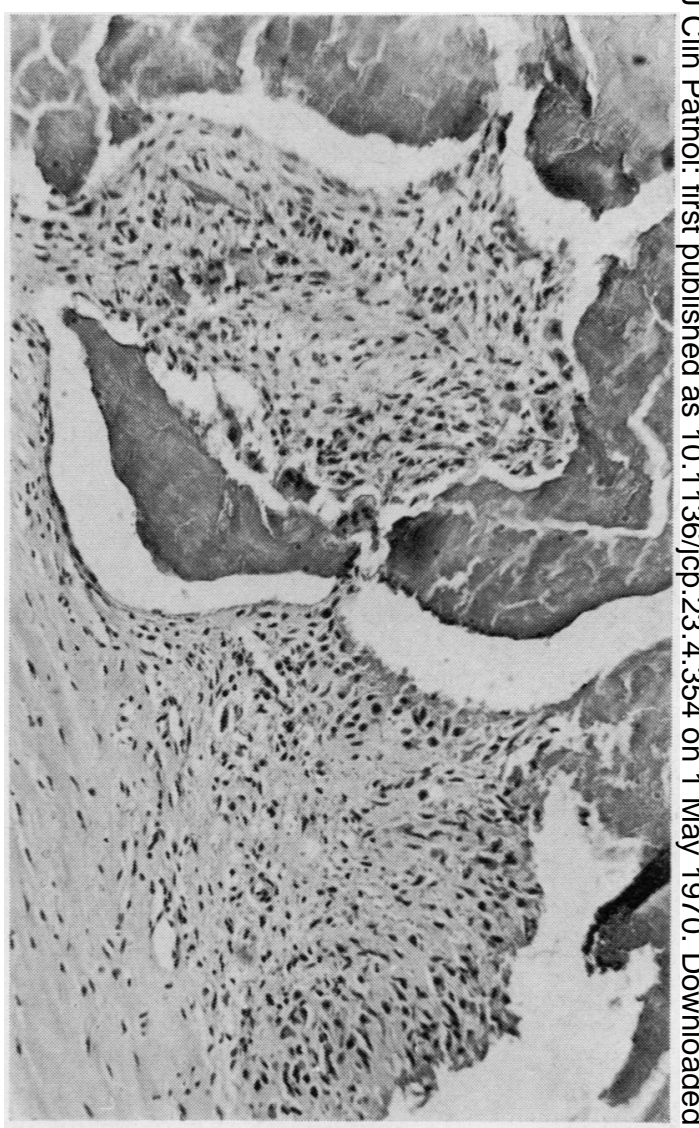

Fig. 11 Section through calcified mitral ring showing chronic inflammatory changes, multinucleate giant cells, and pallisaded arrangement of fibroblasts (haematoxylin and eosin, $\times 140$ ).

lactation on cardiac calcification in experimental animals (Záhoř and Czabanová, 1964 and 1965).

\section{Discussion}

The presence of cardiovascular signs and symptoms has been recorded in earlier studies of mitral ring calcification. Systolic murmurs were noted in half (Ashworth, 1946) to all (Korn, De Sanchs, and Sell, 1962) patients in the smaller series, and in half to two thirds of the three larger groups (Fertman and Wolff, 1946; Geill, 1951; Simon and Liu, 1954). Indeed, mitral ring calcification is the commonest abnormality found in elderly patients with systolic murmurs (Pomerance, 1968). The present study has shown that these murmurs were usually associated with distortion and atrial displacement of the posterior mitral cusp by calcified spurs, and it seems likely that this deformity, coupled with restriction of normal ring contraction, results in incompetence. Mitral incompetence was the 
clinical diagnosis in one third of the 59 patients (Simon and Liu, 1954) and in all of the 14 cases described by Korn et al (1962). In cases without apparent distortion of cusps possible explanations for systolic murmurs are vibration of the ring (Geill and Kiaer, 1952) or vortex formation around an obstruction (Bruns, 1959). The latter seems most probable in those cases with early localized calcification at the junction of the posterior cusp and intraventricular septum.

The role of mitral ring calcification in cardiac failure has already been considered in a previous paper (Pomerance, 1965). Although failure was present in over half the cases, ring calcification was the only cardiac abnormality in $3 \%$. The question is also discussed in recent text-books of cardiology; Friedberg (1966) states that the frequency of clinical abnormalities in mitral ring calcification was due to associated rheumatic or ischaemic heart disease and not to calcium deposition, while Hurst and Logue (1966) state that ring calcification can produce cardiac failure which may be mistakenly diagnosed as rheumatic or ischaemic. Fertman and Wolff (1946) considered mitral ring calcification an indication of other significant cardiac disease but Geill (1951), from his survey of 230 cases, concluded that it was an independent disease process, unrelated to other cardiac abnormalities. The present author's experience confirms Geill's view and also the suggestion of Simon and Liu (1954) that the effect of ring calcification is further impairment of cardiac function in hearts already diseased.

Complete or bundle-branch block, present in 10 of the 25 electrocardiographs available in the present series, was also noted in earlier studies (Yater and Cornell, 1935; Ashworth, 1946; Rytand and Lipsitch, 1946; Grayson, 1948; Fertman and Wolff, 1946; Simon and Liu, 1954; Korn et al, 1962). This is not surprising since the bundle of His and its main branches are in the area adjacent to the membranous septum which is one of the earliest regions involved in ring calcification.

The pathology of mitral ring calcification has received comparatively little attention. Edwards (1961) includes an illustration of caseation in a calcified ring similar to most of the seven examples in the present survey. This finding seemed of no practical significance other than possibly misleading the inexperienced pathologist into a diagnosis of cardiac tuberculosis. The more commonly seen ulceration of solid calcium through the valve cusp was, however, associated with endocarditis, including two cases with large pedunculated thrombi and a third with emboli from staphylococcal vegetations. Guthrie and Fairgrieve (1963) also record fatal embolism from a myxoid thrombotic mass originating on an ulcerated calcified mitral ring.

There is equally little work on the microscopic changes associated with mitral ring calcification.
Korn et al (1962) noted chronic inflammatory $\bar{\Omega}_{\Omega}$ cells and old and recent haemorrhage. This finding is to be anticipated around calcified 0 masses in a repeatedly contracting organ, and it is therefore surprising that recent haemorrhage $\frac{0}{-}$ was not seen more often in the present study, $\vec{\Rightarrow}$ although haemosiderin-filled macrophages weres common. The finding of foreign-body type giant? cells was similarly not unexpected; it seems likely that these reactions contribute to further extension of the calcification. The pallisading 2 observed in two cases in the present series was of interest in view of the ring lesions described inrheumatoid disease (Cruikshank, 1958); however, neither patient had clinical rheumatoid arthritis. $\vec{\omega}$ The dilated vessels and nonspecific chronic inflammatory cell infiltration present in overo half the cases were also noted by Rosenthal andi Feigin (1947) but the presence of similar inflam-i matory changes in the valve cusp does not appearcu to have been recorded previously. As neither ${ }^{+}$ thrombosis nor infection was observed except 은 where calcium had penetrated the endocardium the inflammatory reaction is presumably of no clinical significance, but the finding is of interest $<$ when considering pathogenesis since it was over $\overrightarrow{0}$ twice as frequent in females.

It is generally agreed that rheumatic or otheri endocarditis is not related to the development of mitral ring calcification although Lannigan (1966) considers Brucella infection a possible factor. The present study confirms the majority view: the incidence of rheumatoid disease, rheumatic or nonspecific post-inflammatory valve changes was no greater than usually found in this age group (Pomerance, 1965). Yater and Cornell (1935) suggested that calcification may be related to mechanical stress, and hyper $\frac{8}{8}$ tension might therefore be a factor in ringo calcification, but no such relationship was demonstrable in my series or in Ashworth's cases (1946). The advanced age of patients with mitral ring calcification points to a de-o generative process, related to other forms of calcific cardiovascular disease, and correlation with aortic atherosclerosis was indeed present. However, this was statistically significant only in women and severe coronary atherosclerosis ${ }_{0}$ was no commoner in hearts with calcified N mitral rings than in those without. Sell ando Scully's demonstration (1965) of increasing valvular sudanophilic deposits and calcification with age offers some support for a degenerative $\stackrel{?}{?}$ hypothesis but does not satisfactorily account 7 for development of mitral ring calcificationo independent of similar aortic valve disease in most cases, nor for the marked sex difference. $\mathbb{D}_{0}$ Because senile osteoporosis is also commoner $\frac{\varrho}{\sigma}$ in women, Blankenhorn (1964) postulated some factor affecting body calcium distribution be- -0 tween bone and soft tissue which is more actives in elderly females. The existence of such a factorō would explain the sex incidence of ring calcifi-? 
cation but would still not account for the predominantly mitral localization. The greater incidence in women also points to pregnancy as a possible aetiological factor, particularly as breeding is associated with cardiovascular calcification in rats (Gillman and Hathorn, 1959); however no correlation between parity and ring calcification was present.

A possible explanation for both location and sex incidence was suggested by pathological findings in the present study. Not only was calcification more often severe, but complicationsulceration, endocarditis, and caseation-occurred almost exclusively in women, and the incidence of valvular chronic inflammatory cell infiltration was twice as high as in men. No comparable changes were present in a series of calcified aortic valves from patients of both sexes. This suggests that in women the mitral valve region may be prone to an exaggerated response to injury, a possibility reinforced by the increased incidence of mitral stenosis in women (Wood, 1968) following rheumatic fever. Whether the initial stimulus is trauma, such as might be expected at the junction of fibrous ring and contracting muscle, or calcification in lipoid infiltration (Sell and Scully, 1965) is speculative, but either would apply equally well to aortic and mitral valves and to both sexes. The additional factor of a differing response in females would account for both the location and sex incidence of calcification of the mitral ring.

\section{References}

Ashworth, C. T. (1946). Atherosclerotic valvular disease of the heart. Arch. Path., 42, 285-298.

Blankenhorn, D. H. (1964). The relation of age and sex to diffuse aortic calcification in man. J. Geront., 19, 72-77.

Bruns, D. L. (1959). A general theory of the causes of murmurs in the cardiovascular system. Amer. J. Med., 27, 360-374.

Cruickshank, B. (1958). Heart lesions in rheumatoid disease. J. Path. Bact., 76, 223-240.
Edwards, J. E. (1961). An Atlas of Acquired Diseases of the $C$ Heart and Great Vessels, p. 385. Saunders, Philadelphia? and London.

Fertman, M. H., and Wolff, L. (1946). Calcification of the mitral valve. Amer. Heart J., 31, 580-589.

Friedbərg, C. K. (1966). Diseases of the Heart, 3rd ed. Saunders, Pniladelphia and London.

Geill, T. (1951). Calcification of the left annulus fibrosus. J. Geront., 6, 327-333.

Geill, T., and Kiaer, W. (1952). Further investigations into changes $\stackrel{5}{\circ}$ of aging in the left atrioventricular fibrous ring. Acta med.ర scand., Suppl. 266, 413-417.

Gillman, T., and Hathorn, M. (1959). Sex incidence of vascular lesions in aging rats in relation to previous pregnancies. $\frac{\omega}{7}$ Nature (Lond.), 183, 1139-1140.

Grayson, C. E. (1948). Cardiac calcification, annular and valvular (leaflet). Calif. Med., 68, 121-125.

Guthrie, J., and Fairgrieve, J. (1963). Aortic embolism due to myxoid tumour associated with myocardial calcification. $\overrightarrow{0}$ Brit. Heart J., 25, 137-140. Hudson, R. E. B. (1965). Cardiovascular Pathology, vol. 2, $\vec{\omega}$
p. 1316. Arnold, London.

Hurst, J. W., and Logue, R. B. (1966). The Heart, p. 560, McGrawHill, New York.

Korn, D., DeSanctis, R. W., and Sell, S. (1962). Massive calcification of the mitral annulus. New Engl. J. Med., 267, $N$ 900-909.

Lannigan, R. (1966). Cardiac Pathology, p. 177, Butterworth London.

New England Journal of Medicine. (1962). Os cordis (Editorial). 267, 941 .

Pomerance, A. (1965). Pathology of the heart with and without cardiac failure in the aged. Brit. Heart J., 27, 697-710.

Pomerance, A. (1968). Cardiac pathology and systolic murmurs in the elderly. Brit. Heart J., 30, 687-689.

Rosenthal, J., and Feigin, I. (1947). Pathology of the mitral valve in the older age groups. Amer. Heart J., 33, 346-361.

Rytand, D. A., and Lipsitch, L. S. (1946). Clinical aspects of calcification of the mitral annulus fibrosus. Arch. intern. Med., 78, 544-564.

Sell, S., and Scully, R. E. (1965). Aging changes in the aortio and mitral valves. Amer. J. Path., 46, 345-365.

Simon, M. A., and Liu, S. F. (1954). Calcification of the mitraP valve annulus and its relation to functional valvulap disturbance. Amer. Heart J., 48, 497-505.

Wood, P. (1968). Diseases of the Heart and Circulation, 3rd ed. D p. 614. Eyre and Spottiswoode, London.

Yater, W. M., and Cornell, V. H. (1935). Heart block due to $\overrightarrow{\vec{\sigma}}$ calcareous lesions of the bundle of His. Ann. intern. Med. 8,777-789. Wright, G. P. and Symmers, W. St. C. (1966). Systematic Path $\frac{\text { Tे }}{\text { ology. Longmans, London. }}$
.

Záhoř, Z., and Czabanová, V. (1964). The importance of lac:tation in spontaneous postgestation mediocalcinosis and arteriosclerosis in rats. J. Atheroscler. Res., 4,435-443.

Záhoř, Z., and Czabanová, V. (1965). The significance of forced weaning of the young in the pathogenesis of postgesta tional aortic lesions in rats. J. Atheroscl. Res.. 5, 338-340. 